\title{
Exendin-4 dose not evoke pancreatitis or pancreatitis-associated histopathological and genetic changes in high-fat diet induced diabetic mice.
}

\author{
Yi-Qiong Sun\#, Chang Guo ${ }^{\#}$, Qiang Li*, Lin Guo, Li-Li Chen, Wei Wang, Jin-Chao Zhang \\ Department of Endocrinology and Metabolism, Second Affiliated Hospital of Harbin Medical University, Harbin, PR China
}

${ }^{\#}$ These authors contributed equally to this work

\begin{abstract}
Background: Clinical reports have suggested the potential link of Glucagon-Like Peptide 1 Receptor Agonists (GLP-1RAs) with the development of pancreatitis. We investigated the effects of long-term exposure of Exendin-4 (Ex-4), a kind of GLP-1RA, on biochemical, histological and genetic markers of pancreatitis in High-Fat Diet (HFD) induced mice.

Methodology: HFD induced mice received subcutaneous twice-daily injections of Ex-4 (3 and 30 $\mu \mathrm{g} / \mathrm{kg} / \mathrm{d}$ ) or vehicle for $12 \mathrm{w}$. Pancreatitis was induced with Caerulein (CRN) in Ex-4 treated mice or wild mice. Changes in body weight, food consumption, serum amylase, serum lipase, glucose, and insulin concentrations were measured in each group. An extended histopathological and ultralstructural by transmission electron microscopy evaluation of exocrine pancreas was performed. The expressions of pancreatitis-associated microRNAs and genes were assessed by real-time PCR.

Results: Ex-4 improved physical condition, glucose concentrations, decreased food intake, and increased serum insulin sensitivity in HFD induced mice. No deleterious effects on serum amylase and lipase were observed after Ex-4 treatment. The histopathological and ultralstructural findings did not reveal adverse effects of Ex-4. Ex-4 administration did not significantly modify the level of pancreatitisassociated microRNAs (miR-181, miR-148, miR-210 and miR-216a) or pancreatitis-associated genes (RegIII, MCP-1 and IL-6). However, we noted slightly pancreatitis ultralstructural changes in one mouse from $30 \mu \mathrm{g} / \mathrm{kg} / \mathbf{d ~ E x - 4 - t r e a t e d ~ g r o u p . ~}$

Conclusion: Ex-4 does not affect biochemical, histopathological or genetic markers of pancreatitis in HFD induced mice. However, surveillance for a possible increased risk of pancreatitis under excess GLP-1RAs administration is warranted to ensure at least benefits far outweigh potential risks.
\end{abstract}

Keywords: Exendin-4, GLP-1, MicroRNA, Proliferation, Pancreatitis, Caerulein, Amylase.

Accepted on November 20, 2017

\section{Introduction}

Incretin-based therapies, Glucagon-Like Peptide 1 Receptor Agonists (GLP-1RAs) and enzyme dipeptidyl peptidase 4 inhibitors, are emerging as an important drug class for the treatment of Type 2 Diabetes Mellitus (T2DM) [1,2]. It is recommended their use after metformin monotherapy fails to lower $\mathrm{HbA} 1 \mathrm{c}$ to targets levels in current treatment guidelines [2]. Exendin-4 (Exenatide, Ex-4) is a 39-amino acid agonist of the GLP-1 receptor that is approved as an adjunctive treatment for T2DM [3]. A growing body of evidence shows that GLP-1RAs can enhance insulin secretion, inhibit glucagon secretion, and inhibit $\beta$-cell apoptosis [3].

Although Ex-4 is generally well tolerated, post-marketing cases reported possible Ex-4-associated acute pancreatitis [3-6]. Analyses of the FDA Adverse Event Reporting System database and health insurance data have raised concerns about a potential increase in pancreatitis with use of GLP-1RAs based therapies $[7,8]$. However, recent epidemiological studies have demonstrated GLP-1RAs treatment does not appear to increase the risk of acute pancreatitis in patients with T2DM [9-12]. Further, obesity and/or T2DM themselves are risk factors for the development of pancreatitis and obesity increases pancreatitis severity and mortality rate [13-15]. Therefore, a statistical relationship between Ex-4 administration and pancreatitis remains to be demonstrated. The association between Ex-4 administration and the potential adverse pancreatic effects has been investigated in several animal studies with conflicting findings [16-23]. Several preclinical studies and mechanistic studies on Ex-4 conducted in different species, using different routes of administration and different durations showed no manifestations of pancreatitis based on the results of pancreatic function or histomorphology. Moreover, Ex-4 attenuated chemically induced pancreatitis in different diabetic models [18,21-23]. In contrast, it is shown that pre-cancerous and dysplastic changes to pancreas in organ donors exposed to incretin minetics [16]. Similarly, chronic treatment with Ex-4 has been reported to increase the signs of 
pancreatitis with increased degree of inflammation and pyknotic nuclei [20]. Furthermore, the elevated GLP-1 level was possibly responsible for sitaliptin-associated ductal metaplasia and increased duct cell proliferation in a transgenic rat model of T2DM [19]. The increased ductal cell proliferation and accelerated formation of dysplastic lesions without changes in pancreatic enzyme were described in a previous study [17].

The aim of present study was to comprehend the role of Ex-4, a kind of GLP-1 RA, in potential inducing or modulating pancreatitis in animal models. Serum amylase and lipase concentration were measured. The expressions of microRNAs and pancreatitis-associated genes known to be associated with the development of inflammation or pancreatitis were assessed in High-Fat Diet (HFD) induced mice after $13 \mathrm{w}$ administration of Ex-4. We also present the histopatholgical and electron microscopy ultralstructural assessment of pancreata from HFD induced mice treated with Ex-4 for $13 \mathrm{w}$ and mice with CRN-induced pancreatitis.

\section{Materials and Methods}

\section{Animals}

This study has been approved by the Ethics Committee of Second Affiliated Hospital of Harbin Medical University. All procedures were performed in accordance with the internationally accepted Principles of Laboratory Animal Care. Four-week-old male C57BL/6 mice were purchased from Vital River Laboratories (Beijing, China) and acclimated for $7 \mathrm{~d}$ before experiments. Animals were housed individually $\left(21-24^{\circ} \mathrm{C}\right.$, humidity $30-70 \%, 12: 12 \mathrm{~h}$ light cycle) with ad libitum access to water and Standard Chow Diet (SCD, 10\% of calories derived from fat; D12450B) or a HFD (60\% of calories derived from fat; D12492) (Research Diets, New Brunswick, NJ). Mice were weighed weekly to adjust drug doses. Food conception and water intake were measured at each week and the termination of each study.

\section{Generation of high-fat-diet induced diabetic model and experimental pancreatitis model}

Five-week-old male C57BL/6 mice fed HFD for 10 weeks to generate the diabetic mouse model [24]. After $10 \mathrm{w}$ of HFD feeding, oral glucose tolerance tests were performed for three consecutive days. Individual mice with hyperglycemia (fasting blood glucose $\geq 145 \mathrm{mg} / \mathrm{dL}$; blood glucose at $2 \mathrm{~h}$ post-oral glucose challenge $\geq 300 \mathrm{mg} / \mathrm{dL}$ ) were identified as diabetic mice model for later experiments. The diabetic mice were kept on the HFD throughout the study.

The CCK receptor agonist caerulein (CRN, Glbiochem, Shanghai) reconstituted in saline was used to induce acute experimental pancreatitis by five consecutive hourly intraperitoneal (ip) injections $(50 \mu \mathrm{g} / \mathrm{kg})$ in fasted animals. Control mice were administered by saline injections of the same volume.

\section{EX-4 administration}

To assess whether prior GLP-1R activation exacerbates the subsequent development of pancreatitis, Exendin-4 (Ex-4, Bachem, Switzerland) was administered as twice daily subcutaneous dose (3 or $30 \mu \mathrm{g} / \mathrm{kg} / \mathrm{d}$ ) in HFD induced mice for $12 \mathrm{w}$ prior. $\mathrm{CRN}$ was administered after Ex-4 administration in HFD induced mice, to assess the effects of chronic pretreatment with Ex-4 on $\mathrm{CRN}$-induced pancreatitis. Ex-4 treatment animals were dose-titrated during the first $7 \mathrm{~d}$ to avoid adipsia-induced dehydration. CRN was used to induce acute experimental pancreatitis model in SCD mice. There were 8 mice in control group, 8 mice in experimental pancreatitis model group and 8 mice in diabetic control group. Diabetic animals were randomly allocated into four groups of 8 animals in 4 treatment groups (Table 1).

\section{Clinical chemistry}

For oral glucose tolerance tests, mice were fasted for $8 \mathrm{~h}$ and then given D-glucose ( $3 \mathrm{~g} / \mathrm{kg}$, Amresco) orally. Blood samples were collected by retro-orbital sinus puncture at 0,30 and 120 min after glucose administration. Blood glucose concentration was determined with OneTouch ultra-blood glucose meter (LifeScan, Milpitas, USA). Following centrifugation at $4^{\circ} \mathrm{C}$, serum was separated and stored at $-80^{\circ} \mathrm{C}$ until analysis. Serum insulin, amylase and lipase were assessed with ELISA kits according to assay protocols (mouse insulin ELISA, Mercodia, Sweden. mouse Amylase Alpha 2 ELISA kit, mouse Lipase ELISA kit, Life Science Inc., Wuhan, China). Pancreatic $\beta$-cell function was calculated as the difference in values between 0 and $30 \mathrm{~min}$, using the following equation: $\Delta \mathrm{I}_{30} / \Delta \mathrm{G}_{30}=\left(\mathrm{I}_{30^{-}}\right.$ $\left.\mathrm{I}_{0}\right) /\left(\mathrm{G}_{30}-\mathrm{G}_{0}\right)$. HOMA-IR was calculated as described [25] by using the equations: $\mathrm{HOMA}-\mathrm{IR}=(\mathrm{FPG} \times \mathrm{FPI}) / 22.5$. $\mathrm{FPI}$ is fasting plasma insulin concentration $(\mathrm{mU} / \mathrm{L})$ and $\mathrm{FPG}$ is fasting plasma glucose $(\mathrm{mmol} / \mathrm{L})$.

\section{Histological assessment}

All animals anesthetized with $\mathrm{CO}_{2}$ before decapitation. For histological assessment, the head pieces of pancreas were removed and immediately fixed in $4 \%$ buffered formaldehyde and embedded in paraffin according to standard histological procedures. Sections $(5 \mu \mathrm{m})$ were cut and stained with hematoxylin-eosin. The total surface of the slides was scored for six different variables determining severity of inflammation by two blinded board-certified pathologists. The six different variables were: edema, acinar necrosis, hemorrhage, fat necrosis, inflammation and perivascular infiltrate. The standardized scoring system was applied as described before [26]. At the end of the investigations for each group, the mean total score and the mean score of each histopathologic finding were determined. The sections were incubated with anti-Ki-67 antibody (rabbit anti-Ki-67, Abcam, 1:100) overnight at $4^{\circ} \mathrm{C}$. The sections were then incubated with a peroxides-labeled polymer-conjugated anti-rabbit secondary antibody (Boster, Wuhan, China) at $37^{\circ} \mathrm{C}$ for $30 \mathrm{~min}$. The sections were stained with 3, 3-Diaminobenzidine (DAB, Beijing Zhong Shan Biotech Co. Ltd, Beijing, China) for $3 \mathrm{~min}$ and nuclei 
counterstained with hematoxylin. The slides were imaged using Nikon DS Ril (Tokyo, Japan) and analysed using the Image-Pro Plus 6.0 software (Media Cybernetics, Inc. Silver Spring, USA).

\section{Transmission electron microscopy assessment}

The ultra-structure of pancreas was examined using transmission electron microscopy as described previously. The pancreas blocks were fixed in clod $2.5 \%$ glutaraldehyde, $2 \%$ paraformaldehyde, and $1 \%$ tannic acid in $0.1 \mathrm{M}$ cacodylate buffer ( $\mathrm{pH} 7.2$ ). Fixed sections were treated with cold $0.5 \%$ osmium tetroxide, stained in $2 \%$ uranyl acetate and dehydrated through a graded ethanol series. Sections were infiltrated and embedded in an epoxy resin. The ultrathin sections $(60-80 \mathrm{~nm})$ were grid double stained with uranyl acetate and lead citrate and imaged digitally with Hitachi 7650 transmission electron microscope (Tokyo, Japan).

\section{Quantitative real-time PCR}

RNA was extracted from tissues using an RNA extraction kit (OMEGA, USA) according to the Manufacturer's instructions. The miRNA was reverse transcribed using a miRcute miRNA First-Strand cDNA Synthesis kit and detected using a miRcute miRNA qPCR Detection kit (TIANGEN BIOTECH, Beijing, China). The RNA was converted to cDNA using a Quant FirstStrand cDNA Synthesis kit and detected using a RealMaster Mix Detection kit (TIANGEN BIOTECH, Beijing, China). The PCR products were fluorometrically quantified using SYBR Green, normalized to a housekeeping gene 5S or GAPDH and expressed relative to the control. Analysis of real-time PCR data was evaluated using the $2^{-\Delta \Delta \mathrm{Ct}}$ method.

The specific primers were described in Table 2.

\section{Statistical analysis}

Data are presented as means \pm SEM. All results are graphed using GraphPad Prism 5 (GraphPad Software, San Diego, CA, USA). Statistical differences between treatment groups and appropriate controls were assessed with one-way ANOVA followed by Bonferroni's multiple comparison-test using SPSS.18. Statistical significance was set at $\mathrm{P}<0.05$.

\section{Results}

\section{Body weight, food intake and glycaemic control}

Overall weight loss and mean food intakes of mice administered with Ex-4 were lower than those of vehicle animals overall $(\mathrm{p}<0.01) . \Delta \mathrm{I}_{30} / \Delta \mathrm{G}_{30}$, the insulinogenic index, in Ex-4 treated groups ( 3 and $30 \mu \mathrm{g} / \mathrm{kg} / \mathrm{d}$ ) significantly differed from that in HFD vehicle group $(\mathrm{p}<0.01$, Figure $1 \mathrm{~A})$. An indicator of insulin resistance, HOMA-IR index, was significantly reduced in two Ex-4 treatment groups than in vehicle group $(\mathrm{p}<0.01$, Figure 1B).
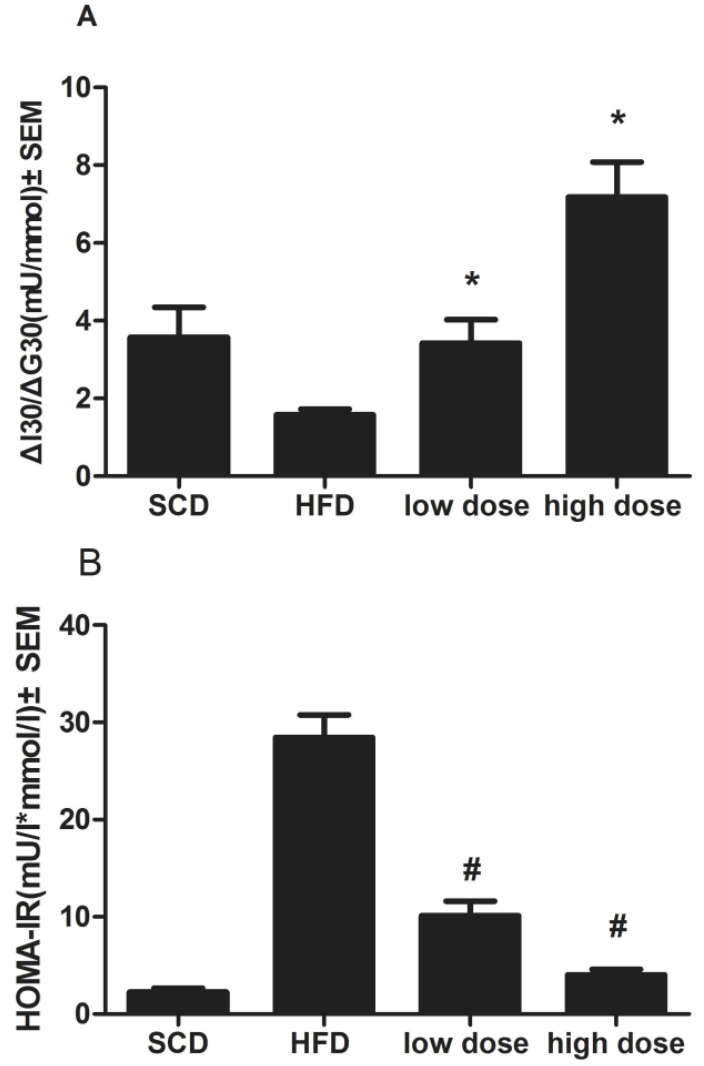

Figure 1. $I_{30} / G_{30}$ (A) and HOMA-IR (B) in mice dosed with intraperitoneal injections of different doses of Ex-4 (3 and 30 $\mu \mathrm{g} / \mathrm{kg} / \mathrm{d}$ ) or vehicle, and in wild SCD mice. ${ }^{*} p<0.05$, both low- and high-dose of Ex-4 groups versus HFD control. Data were mean \pm SEM, $n=8$.

\section{Biochemical markers of pancreatitis}

$12 \mathrm{w}$ of Ex-4 administration ( 3 and $30 \mu \mathrm{g} / \mathrm{kg} / \mathrm{d}$ ) had no effect on serum amylase or lipase concentrations compared with SCD or HFD controls (Figures 2A and 2B). But, they were markedly reduced in Ex-4 (3 and $30 \mu \mathrm{g} / \mathrm{kg} / \mathrm{d}$ ) treated mice compared with CRN induced experimental pancreatitis model mice $(\mathrm{p}<0.01$, Figures $2 \mathrm{~A}$ and $2 \mathrm{~B})$. To examine whether a longer duration of Ex-4 exposure affected pancreatitis-related end points in HFD induced mice, CRN was administered following $12 \mathrm{w}$ subcutaneous infusions of Ex-4. Lipase and amylase activities were slightly lower with no significance $\mathrm{P}=0.14$, and $\mathrm{P}=0.33$, representatively, in $12 \mathrm{w} \mathrm{Ex}-4$ pre-treatment groups compared to solely $\mathrm{CRN}$-induced pancreatitis group (Figures 2C and 2D).

\section{Light microscopy and transmission electron microscopy evaluation of pancreas}

The main histopathological pancreas findings from the terminally euthanized animals are compiled in Table 3. CRN produced cellular infiltration, necrosis of acinar tissue and cells, and hemorrhage in experimental pancreatitis model pancreas (Figure 3D). 
The incidence and severities of focal ductal proliferation and chronic periductal inflammation in Ex-4 treated animals extremely resembled those of in HFD vehicle mice (Figures $3 \mathrm{~A}-3 \mathrm{C}$, Table 3 ). The rate of ductal cell proliferation was low $(<1 \%)$ and similar in EX-4 treated groups and HFD group.
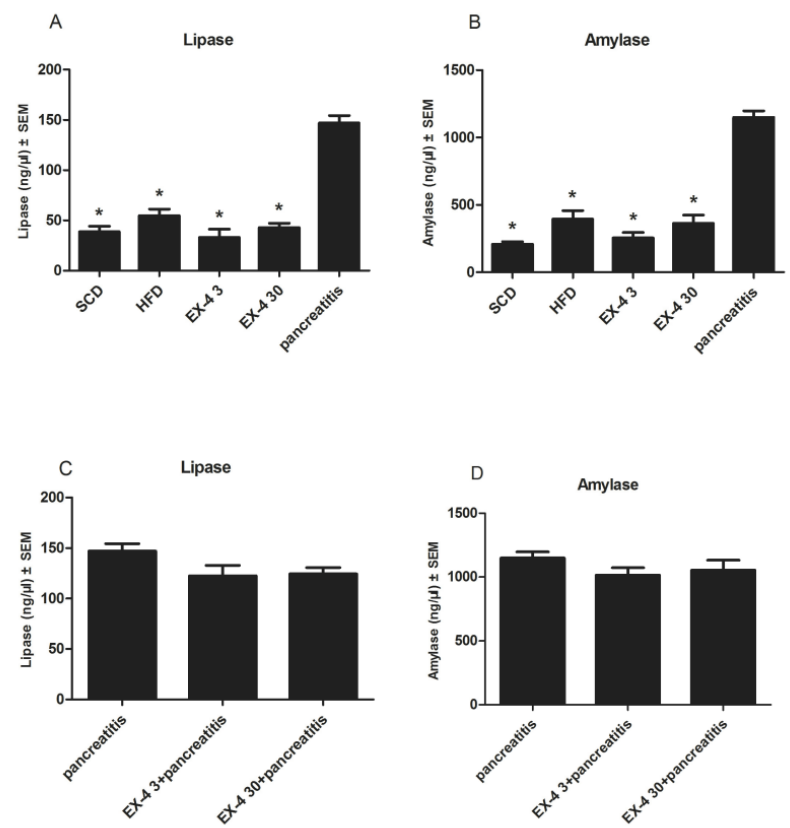

Figure 2. Serum lipase (A) and amylase (B) in experimental pancreatitis mice and in mice dose with intraperitoneal injections of different doses of Ex-4 (3 and $30 \mu \mathrm{g} / \mathrm{kg} / \mathrm{d}$ ) or vehicle, and in HFD control mice. Lipase (C) and amylase (D) in experimental pancreatitis mice pre-treated with different doses of Ex-4 (3 and 30 $\mu \mathrm{g} / \mathrm{kg} / \mathrm{d}$ ) or vehicle. ${ }^{*} p<0.05$, all the other groups versus pancreatitis group, Data were mean $\pm S E M, n=8$.

In this study, we further investigated the pancreatic ultrastructure of the mouse treated with Ex-4 or vehicle using transmission electron microscopy. We found that there were no obvious differences in Ex-4 treated groups and HFD group, including zymogen granule, aciner duct chamber and mitochondrion.

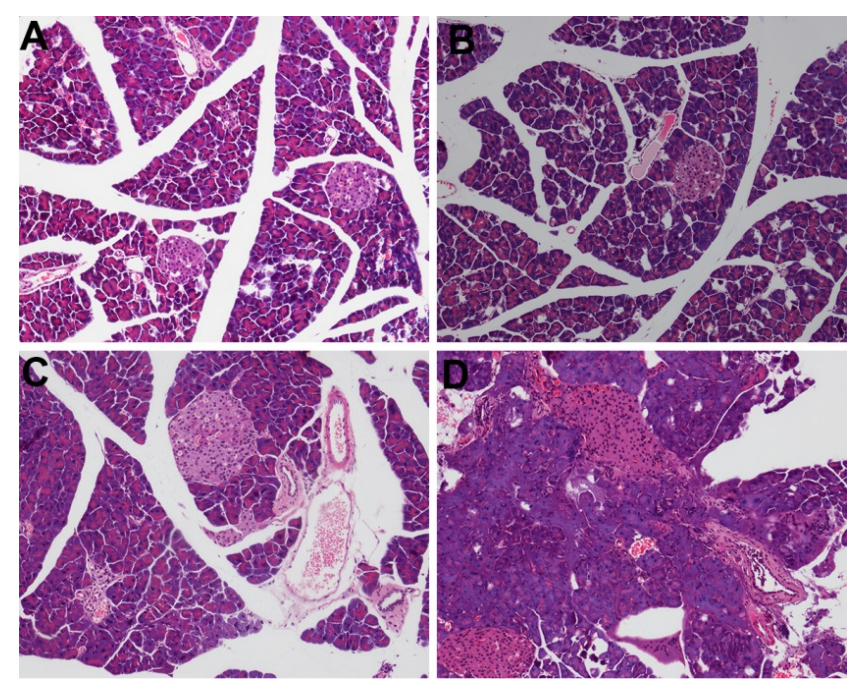

Figure 3. Representative sections from pancreata of C57/BL6 mice. A: HFD control mice, B: low-dose EX-4 (3 $\mu \mathrm{g} / \mathrm{kg} / \mathrm{d})$ treated mice, $C$ : high -dose Ex-4 (30 $\mu \mathrm{g} / \mathrm{kg} / \mathrm{d})$ treated mice, D: experimental pancreatitis mice stained for HE. Magnification X100.

\section{Effects of EX-4 on expression of miRNAs and genes associated with pancreatitis}

As expected, the expression of all the four miRNAs (miR-181, miR-148, miR-210 and miR-216a) and genes in pancreatitis group showed a remarkably increase compared to other groups $(\mathrm{P}<0.01)$. As shown in Table 4, neither low- nor high-dose Ex-4 administration modifies the levels of these four miRNAs compared to HFD vehicle group. Moreover, levels of these four miRNAs exhibited similar between the two Ex-4 groups. Neither low- nor high-dose Ex-4 treatment showed any further increase in the expression of three genes (RegIII, MCP-1 and IL-6) compared to HFD control group. No significant difference in the levels of above three genes was observed between high- and low-dose Ex-4-treated groups.

Table 1. Study design. BID, twice daily; IP: Intraperitoneal; D12450B/SCD, standard chow diet, 10\% fat, research diets; D12492/HFD, high-fat diet, $60 \%$ fat, research diets; CRN: Caerulein.

\begin{tabular}{|c|c|c|c|c|c|}
\hline & $\begin{array}{l}\text { Number } \\
\text { animals }\end{array}$ & of Diet & Treatment/time (w) & $\begin{array}{l}\text { Nominal dose (BID subcutaneous } \\
\text { injection) }\left(\mu \mathrm{g} / \mathrm{kg}^{-1 / 1} / \mathrm{d}^{-1}\right)\end{array}$ & $\begin{array}{l}\text { Induced pancreatitis } \\
(50 \mu \mathrm{g} / \mathrm{kg})\end{array}$ \\
\hline Control & $\mathrm{N}=8$ & D12450B/SCD & Vehicle/13 & 0 & 0 \\
\hline HFD & $N=8$ & D12492/HFD & Vehicle/13 & 0 & 0 \\
\hline HFD+Ex-4 low & $N=8$ & D12492/HFD & $E x-4 / 13$ & 3 & 0 \\
\hline HFD+Ex-4 high & $\mathrm{N}=8$ & D12492/HFD & $E x-4 / 13$ & 30 & 0 \\
\hline $\mathrm{HFD+CRN}$ & $N=8$ & D12492/HFD & Vehicle/13 & 0 & $\mathrm{CRN} \times 5$ \\
\hline HFD+Ex-4 low + C RN & $N=8$ & D12492/HFD & Ex-4/13 & 3 & $\mathrm{CRN} \times 5$ \\
\hline HFD+Ex-4 high+C RN & $N=8$ & D12492/HFD & $E x-4 / 13$ & 30 & $\mathrm{CRN} \times 5$ \\
\hline
\end{tabular}

Table 2. The specific primers used in PCR.

Name Primers


Exendin-4 dose not evoke pancreatitis or pancreatitis-associated histopathological and genetic changes in high-fat diet induced diabetic mice

\begin{tabular}{ll}
\hline \multirow{2}{*}{ GAPDH } & Forward: 5-GGTGAAGGTCGGTGTGAACG-3 \\
\cline { 2 - 2 } & Reverse: 5 -CTCGCTCCTGGAAGATGGTG-3 \\
\hline \multirow{2}{*}{ MCP-1 } & Forward: 5-GGCTTCATTCTTGTCCTCCA-3 \\
\cline { 2 - 2 } & Reverse: 5 -TTGTTACTCCATTCCCATCCA-3 \\
\cline { 2 - 2 } & Reverse: 5 -TACAGCTTCTTTGGGACACCTGCT-3 \\
\hline IL-6 & Forward: 5-CCACTCCCAACAGACCTGTCTATAC-3 \\
\cline { 2 - 2 } & Reverse: 5 -CACAACTCTTTTCTCATTTCCACGA-3 \\
\hline miR-216a & Forward: 5-GTAATCTCAGCGGGCAACTGTGA-3 \\
\hline miR-146a & Forward:5-GCTGAGAACTGAATTACATGGGTT-3 \\
\hline miR-181a & Forward: 5-AACATTCAACGCTGTCGGTGAGT-3 \\
\hline miR-210 & Forward: 5-CTGTGCGTGTGACAGCGGTTGA-3 \\
\hline
\end{tabular}

Notes: The miRNAs reverse were provided in miRcute miRNA qRCR Detection kit, $5 \mathrm{~S}$ was obtained from Tiangen Biotech

Table 3. Summary of severity of selected histopathological findings in terminally euthanized animals.

\begin{tabular}{lllll}
\hline Microscopy findings & \multicolumn{2}{l}{ Ex-4 dose $(\mu \mathrm{g} / \mathrm{kg} / \mathrm{d})$} & CRN \\
\cline { 2 - 5 } & Vehicle $(\mathbf{n}=\mathbf{8})$ & $\mathbf{3}(\mathbf{n}=7)$ & $\mathbf{3 0}(\mathbf{n}=7)$ & $(\mathbf{n}=\mathbf{8})$ \\
\hline Edema, interstitium & 0.75 & 1.25 & 1.67 & 2.5 \\
\hline Necrosis, adipose tissue & 0.25 & 0.25 & 0.3 & 3 \\
\hline Necrosis, acinar cell & 0.25 & 0.35 & 0.4 & 2.5 \\
\hline Acinar cell atrophy & 0.25 & 0.75 & 0.8 & 2.5 \\
\hline Ductal proliferation & 0.5 & 1 & 1.25 & 2 \\
\hline $\begin{array}{l}\text { Inflammation/perivascular } \\
\text { infiltrate }\end{array}$ & 0.5 & 0.5 & 0.8 & 2.5 \\
\hline Hemorrhage, interstitium & 0 & 0.25 & 0.4 & 3 \\
\hline
\end{tabular}

Table 4. The expression of pancreatitis-associated miRNAs and genes. ${ }^{*} p<0.05$, both Ex-4 groups and HFD group versus pancreatitis group. Values are mean $\pm S E M, n=8$.

\begin{tabular}{|c|c|c|c|c|}
\hline Item & HFD control & HFD+Ex-4 (low dose) & HFD+Ex-4 (high dose) & Pancreatitis \\
\hline Reglll & $1.06 \pm 0.25^{*}$ & $1.12 \pm 0.15^{*}$ & $1.26 \pm 0.17^{*}$ & $3.61 \pm 0.23$ \\
\hline MCP-1 & $0.99 \pm 0.11^{*}$ & $1.06 \pm 0.19^{*}$ & $1.18 \pm 0.3^{*}$ & $2.85 \pm 0.33$ \\
\hline IL-6 & $0.74 \pm 0.30^{*}$ & $0.99 \pm 0.26^{*}$ & $1.26 \pm 0.32^{*}$ & $4.78 \pm 0.90$ \\
\hline $\operatorname{miR}-216 a$ & $1.03 \pm 0.37^{*}$ & $0.92 \pm 0.27^{*}$ & $1.64 \pm 0.47^{*}$ & $5.68 \pm 0.55$ \\
\hline miR-210 & $1.05 \pm 0.22^{*}$ & $1.12 \pm 0.14^{*}$ & $1.67 \pm 0.35^{*}$ & $5.24 \pm 0.97$ \\
\hline miR-181 & $1.02 \pm 0.23^{*}$ & $1.69 \pm 0.31^{*}$ & $2.02 \pm 0.29^{*}$ & $8.23 \pm 0.59$ \\
\hline miR-148 & $1.04 \pm 0.23^{*}$ & $0.96 \pm 0.15^{*}$ & $1.58 \pm 0.21^{*}$ & $5.48 \pm 0.34$ \\
\hline
\end{tabular}

\section{Discussion}

Since GLP-1R is available, the relationship between GLP-1R and pancreatitis has been a hot issue. This study indicated that application of Extendin-4 did not induce pancreatitis in mice, which was consistent with many previous studies [18,21,23]. Meanwhile, many clinical studies showed that application of GLP-1R drugs was not related to occurrence of pancreatitis [27-29]. However, some previous studies reported that GLP-1R drugs could increase risks of pancreatitis, which might be due to high dosage significantly more than regular therapeutic dose (20-50 times).

The beneficial effects of Ex-4 on glucose metabolism and weight loss were observed in this study, consisted with prior animal studies [30-32]. We observed that Ex-4 had no deleterious effects on exocrine pancreas in this study. In Ex-4 treated groups ( 3 and $30 \mu \mathrm{g} / \mathrm{kg} / \mathrm{d}$ ), the levels of serum lipase and amylase, which are specific markers of acute pancreatitis and are expected to rise at least threefold above the upper limit of normal in acute pancreatitis, were similar to those in HFD control group. Furthermore, lipase and amylase activities were slightly lower with $12 \mathrm{w}$ Ex-4 pre-treatment compared to solely $\mathrm{CRN}$-induced pancreatitis group.

The increasing numbers of reports about the development of pancreatitis following Ex-4-treatment raise the possibility that Ex-4 could improve glucose metabolism accompany by undesirable adverse effects of induction of low-grade asymptomatic chronic pancreatitis, and potentially, in the long run, pancreatic cancer $[3,7,8]$. In this study, the dose of Ex-4 that was comparable with or up to 10 times the exposure level in human was used to detect the effects on exocrine pancreas. In general, the histological results for the mice pancreata were in accordance with the levels of plasma amylase and lipase. No histological signs of pancreatitis were found in mice. Based on these observations, we supposed that Ex-4 treatment did not initiate pancreatitis. It might exert protective effects on exocrine pancreas and reduce risks for pancreatitis, which probably resulted from the improvement on glucose metabolism and reduction in glucotoxicity.

Recent studies have noticed a potential link between miRNAs and pancreatitis. Some studies have shown that a class of miRNAs including miR-181, miR-148, miR-216a and miR-210 
are indeed produced abundantly to serve as a potential biomarker candidate for pancreatic injury and may be more sensitive and specific than amylase and lipase [33-36]. These observations raised the hope that some specific miRNAs could be candidate markers for pancreatic injury or pancreatitis. In this study, we observed an increase in the levels of miRNAs (miR-181, miR-148, miR-216a and miR-210) that were supposed to be involved in pancreatitis in HFD group. This was consistent with the opinion that pre-diabetes and diabetes were predisposed to pancreatitis. In addition, we demonstrated that neither low- nor high-dose treatment of Ex-4 change the expression of pancreatitis-associated genes, including $M C P-1$, Reg $W$, and $I L-6$. These results were coincident with the findings in histology and suggested a contrary standpoint to which described Ex-4 expanded expression of pancreatitis associated genes.

However, the association between Ex-4 use and pancreatitis has long been discussed with argument for several explanations. Firstly, one recent study conducted in human donors demonstrated that incretin therapy expanded both endocrine and exocrine pancreas and increased exocrine pancreas dysplasia tended to obstruct the outflow of pancreatic enzymes [16]. This was a plausible mechanism of Ex-4 in relation to pancreatitis, which was also found in our study under electron microscopy. Secondly, pro-inflammatory mediators appear to play a key role in the pathogenesis of pancreatitis and the subsequent inflammatory response [18,37]. A trend towards downregulation was observed for some inflammatory cytokines including IL-2, IFN $\gamma, \mathrm{MCP}-1$, and $\mathrm{TNF} \alpha$ [22]. However, one study has reported that Ex-4 did not show any increase in several inflammatory mediators (IL-1 $\beta$, IL-2, IFN $\gamma$ ), which was consisted with our results. Thirdly, some researchers have speculated the potential risk for pancreatitis may be related to the venomous origin of the Ex-4 peptide from the lizard [3]. Fourthly, Type 2 diabetes and obesity themselves are risk factors for the development of pancreatitis.

Although we demonstrated that the expression of potential pancreatitis-associated genes and miRNAs was altered in response to Ex-4, the exact mechanism still remained unknown. In addition, the expression of miRNAs in pancreatitis mice was not feasible to measure, considering that $5 \mathrm{~h}$ acute CRN treatment was probably not sufficient to modify their expression. Moreover, these preliminary rodent observations could not simply translate to humans, suggesting a requirement of further studies using pancreata from donors in the future.

The FDA, as well as some experts has sent an alert for clinicians to realize the potential risk of Ex-4 use for pancreatitis $[3,7,8,38]$. However, it still does not reach an agreement with existing evidences. Our study provided new evidence for the dispute, presented the electron microscopy to assess pancreata and attempted to find a novel way that involved in miRNAs to underlying the mechanism of Ex-4 induced effects.

\section{Conclusion}

In conclusion, long-term exposure to Ex-4 at concentrations comparable with or up to several-fold therapeutic levels in humans contributed to the expected metabolic benefits in diabetic mice. Chronic low-dose Ex-4 exposure in general was safe, for no signs of change in plasma markers, histology and genes associated with pancreatitis were found. Of concern, we noted slightly pancreatitis in one mouse in high-dose Ex-4treated group. Therefore, surveillance for a possible increased risk of pancreatitis under high dose Ex-4 administration is warranted to ensure at least benefits far outweigh potential risks.

\section{Acknowledgments}

This work was supported by National Natural Science Foundation of China (No. 81170744 andNo.81390902). We would like to thank Rui-Bo Zhao and Qi Huang for expert assistance in histological analysis of this manuscript. We thank Tie-Zhu An for excellent technical assistance.

\section{References}

1. Drucker DJ, Nauck MA. The incretin system: glucagon-like peptide-1 receptor agonists and dipeptidyl peptidase-4 inhibitors in type 2 diabetes. Lancet 2006; 368: 1696-1705.

2. Inzucchi SE, Bergenstal RM, Buse JB, Diamant $M$, Ferrannini E, Nauck M, Peters AL, Tsapas A, Wender R, Matthews DR. Management of hyperglycaemia in type 2 diabetes: a patient-centered approach. Position statement of the American Diabetes Association (ADA) and the European Association for the Study of Diabetes (EASD). Diabetologia 2012; 55: 1577-1596.

3. Ahmad SR, Swann J. Exenatide and rare adverse events. N Engl J Med 2008; 358: 1970-1972.

4. Ayoub WA, Kumar AA, Naguib HS, Taylor HC. Exenatideinduced acute pancreatitis. Endocr Pract 2010; 16: 80-83.

5. Denker PS, Dimarco PE. Exenatide (exendin-4)-induced pancreatitis: a case report. Diab Care 2006; 29: 471.

6. Tripathy NR, Basha S, Jain R, Shetty S, Ramachandran A. Exenatide and acute pancreatitis. J Assoc Phys India 2008; 56: 987-988.

7. Elashoff M, Matveyenko AV, Gier B, Elashoff R, Butler PC. Pancreatitis, pancreatic, and thyroid cancer with glucagon-like peptide-1-based therapies. Gastroenterol 2011; 141: 150-156.

8. Singh S, Chang HY, Richards TM, Weiner JP, Clark JM, Segal JB. Glucagonlike peptide 1-based therapies and risk of hospitalization for acute pancreatitis in type 2 diabetes mellitus: a population-based matched case-control study. JAMA Intern Med 2013; 173: 534-539.

9. Azoulay L, Filion KB, Platt RW, Dahl M, Dormuth CR, Clemens KK, Durand M, Hu N, Juurlink DN, Paterson JM, Targownik LE, Turin TC, Ernst P, Suissa S, Dormuth CR, Hemmelgarn BR, Teare GF, Caetano P, Chateau D, Henry DA, Paterson JM, LeLorier J, Levy AR, Ernst P, Platt RW, Sketris IS. Association between incretin-based drugs and 
the risk of acute pancreatitis. JAMA Intern Med 2016; 176: 1464-1473.

10. Azoulay L, Filion KB, Platt RW, Dahl M, Dormuth CR, Clemens KK, Durand M, Juurlink DN, Targownik LE, Turin TC, Paterson JM, Ernst P. Incretin based drugs and the risk of pancreatic cancer: international multicentre cohort study. BMJ 2016; 352: 581.

11. Knapen LM, de Jong RG, Driessen JH, Keulemans YC, van Erp NP, De Bruin ML, Leufkens HG, Croes S, de Vries F. Use of incretin agents and risk of acute and chronic pancreatitis: A population-based cohort study. Diabetes Obes Metab 2017; 19: 401-411.

12. Storgaard H, Cold F, Gluud LL, Vilsboll T, Knop FK. Glucagon-like peptide-1 agonists and risk of acute pancreatitis in patients with type 2 diabetes. Diabetes Obes Metab 2017.

13. Butler AE, Galasso R, Matveyenko A, Rizza RA, Dry S, Butler PC. Pancreatic duct replication is increased with obesity and type 2 diabetes in humans. Diabetologia 2010; 53: 21-26.

14. Martinez J, Johnson CD, Sanchez-Paya J, de Madaria E, Robles-Diaz G, Perez-Mateo M. Obesity is a definitive risk factor of severity and mortality in acute pancreatitis: an updated meta-analysis. Pancreatology 2006; 6: 206-209.

15. Noel RA, Braun DK, Patterson RE, Bloomgren GL. Increased risk of acute pancreatitis and biliary disease observed in patients with type 2 diabetes: a retrospective cohort study. Diab Care 2009; 32: 834-838.

16. Butler AE, Campbell-Thompson M, Gurlo T, Dawson DW, Atkinson M, Butler PC. Marked expansion of exocrine and endocrine pancreas with incretin therapy in humans with increased exocrine pancreas dysplasia and the potential for glucagon-producing neuroendocrine tumors. Diabetes 2013; 62: 2595-2604.

17. Gier B, Matveyenko AV, Kirakossian D, Dawson D, Dry SM, Butler PC. Chronic GLP-1 receptor activation by exendin-4 induces expansion of pancreatic duct glands in rats and accelerates formation of dysplastic lesions and chronic pancreatitis in the $\operatorname{Kras}(\mathrm{G} 12 \mathrm{D})$ mouse model. Diabetes 2012; 61: 1250-1262.

18. Koehler JA, Baggio LL, Lamont BJ, Ali S, Drucker DJ. Glucagon-like peptide-1 receptor activation modulates pancreatitis-associated gene expression but does not modify the susceptibility to experimental pancreatitis in mice. Diabetes 2009; 58: 2148-2161.

19. Matveyenko AV, Dry S, Cox HI, Moshtaghian A, Gurlo T, Galasso R, Butler AE, Butler PC. Beneficial endocrine but adverse exocrine effects of sitagliptin in the human islet amyloid polypeptide transgenic rat model of type 2 diabetes: interactions with metformin. Diabetes 2009; 58: 1604-1615.

20. Nachnani JS, Bulchandani DG, Nookala A, Herndon B, Molteni A, Pandya P, Taylor R, Quinn T, Weide L, Alba LM. Biochemical and histological effects of exendin-4 (exenatide) on the rat pancreas. Diabetologia 2010; 53: 153-159.
21. Tatarkiewicz K, Belanger P, Gu G, Parkes D, Roy D. No evidence of drug-induced pancreatitis in rats treated with exenatide for 13 weeks. Diabetes Obes Metab 2013; 15: 417-426.

22. Tatarkiewicz K, Smith PA, Sablan EJ, Polizzi CJ, Aumann DE, Villescaz C, Hargrove DM, Gedulin BR, Lu MG, Adams L, Whisenant T, Roy D, Parkes DG. Exenatide does not evoke pancreatitis and attenuates chemically induced pancreatitis in normal and diabetic rodents. Am J Physiol Endocrinol Metab 2010; 299: 1076-1086.

23. Vrang N, Jelsing J, Simonsen L, Jensen AE, Thorup I, Soeborg H, Knudsen LB. The effects of $13 \mathrm{w}$ of liraglutide treatment on endocrine and exocrine pancreas in male and female ZDF rats: a quantitative and qualitative analysis revealing no evidence of drug-induced pancreatitis. Am J Physiol Endocrinol Metab 2012; 303: 253-264.

24. McMurray F, Cox RD. Mouse models and type 2 diabetes: translational opportunities. Mamm Genome 2011; 22: 390-400.

25. Wallace TM, Levy JC, Matthews DR. Use and abuse of HOMA modeling. Diabetes Care 2004; 27: 1487-1495.

26. Schmidt J, Lewandrowski K, Fernandez-del Castillo C, Mandavilli U, Compton CC, Warshaw AL, Rattner DW. Histopathologic correlates of serum amylase activity in acute experimental pancreatitis. Dig Dis Sci 1992; 37: 1426-1433.

27. Funch D, Gydesen H, Tornoe K, Major-Pedersen A, Chan KA. A prospective, claims-based assessment of the risk of pancreatitis and pancreatic cancer with liraglutide compared to other antidiabetic drugs. Diabetes Obes Metab 2014; 16: 273-275.

28. Monami M, Dicembrini I, Nardini C, Fiordelli I, Mannucci E. Glucagon-like peptide-1 receptor agonists and pancreatitis: a meta-analysis of randomized clinical trials. Diabetes Res Clin Pract 2014; 103: 269-275.

29. Monami M, Nreu B, Scatena A, Cresci B, Andreozzi F, Sesti G, Mannucci E. Safety issues with glucagon-like peptide-1 receptor agonists (pancreatitis, pancreatic cancer and cholelithiasis): Data from randomized controlled trials. Diabetes Obes Metab 2017; 19: 1233-1241.

30. Gedulin BR, Nikoulina SE, Smith PA, Gedulin G, Nielsen LL, Baron AD, Parkes DG, Young AA. Exenatide (exendin-4) improves insulin sensitivity and \{beta\}-cell mass in insulin-resistant obese fa/fa Zucker rats independent of glycemia and body weight. Endocrinology 2005; 146: 2069-2076.

31. Rolin B, Larsen MO, Gotfredsen CF, Deacon CF, Carr RD, Wilken M, Knudsen LB. The long-acting GLP-1 derivative NN2211 ameliorates glycemia and increases beta-cell mass in diabetic mice. Am J Physiol Endocrinol Metab 2002; 283: 745-752.

32. Tomas E, Wood JA, Stanojevic V, Habener JF. GLP-1derived nonapeptide GLP-1 (28-36) amide inhibits weight gain and attenuates diabetes and hepatic steatosis in dietinduced obese mice. Regul Pept 2011; 169: 43-48. 
33. Bauer AS, Keller A, Costello E, Greenhalf W, Bier M, Borries A, Beier M, Neoptolemos J, Buchler M, Werner J, Giese N, Hoheisel JD. Diagnosis of pancreatic ductal adenocarcinoma and chronic pancreatitis by measurement of microRNA abundance in blood and tissue. PLoS One 2012; 7: 34151 .

34. Endo K, Weng H, Kito N, Fukushima Y, Iwai N. MiR-216a and miR-216b as markers for acute phased pancreatic injury. Biomed Res 2013; 34: 179-188.

35. Kong XY, Du YQ, Li L, Liu JQ, Wang GK, Zhu JQ, Man XH, Gong YF, Xiao LN, Zheng YZ, Deng SX, Gu JJ, Li ZS. Plasma miR-216a as a potential marker of pancreatic injury in a rat model of acute pancreatitis. World $\mathrm{J}$ Gastroenterol 2010; 16: 4599-4604.

36. Mardin WA, Mees ST. MicroRNAs: novel diagnostic and therapeutic tools for pancreatic ductal adenocarcinoma? Ann Surg Oncol 2009; 16: 3183-3189.
37. Bhatia M, Wong FL, Cao Y, Lau HY, Huang J, Puneet P, Chevali L. Pathophysiology of acute pancreatitis. Pancreatology 2005; 5: 132-144.

38. Faillie JL, Babai S, Crepin S, Bres V, Laroche ML, Le Louet H, Petit P, Montastruc JL, Hillaire-Buys D. Pancreatitis associated with the use of GLP-1 analogs and DPP-4 inhibitors: a case/non-case study from the French Pharmacovigilance Database. Acta Diabetol 2014; 51: 491-497.

\section{*Correspondence to}

Qiang Li

Department of Endocrinology and Metabolism

Second Affiliated Hospital of Harbin Medical University

PR China 